\title{
Their Darkest Hour: the films and photographs of William Grayden and the history of the 'Warburton Range controversy' of 1957
}

\author{
Pamela Faye McGrath and David Brooks
}

This paper discusses the use of documentary films and photographs of Aboriginal people from the Ngaanyatjarra region of Western Australia in the late 1950s during a heated public debate about remote Aboriginal health and welfare. The recruitment of images of people in situations of physical distress to illustrate arguments about political and bureaucratic neglect was controversial, sparking accusations of propaganda and disagreement about the norms of Aboriginal well-being. Some of the images produced, most notably those of Western Australian politician William Grayden, had a significant impact on audiences at the time. Grayden's film, shown in a Perth cinema under the title Their Darkest Hour and sometimes referred to as Manslaughter, is celebrated in recent histories of Aboriginal activism and extracts from it have been used by a new generation of activist filmmakers and artists. The perspectives of the Aboriginal people who appear in Grayden's images are, however, a notable absence in these accounts. When considered alongside other historical sources, local Aboriginal voices reveal a significant visual distortion of the quality of people's lives and the substance of their histories as they are remembered today.

The following research draws on a range of historical and ethnographic information including patrol officer field reports, government correspondence, and interviews with local Aboriginal people and other participants in these events. The perspectives of many Ngaanyatjarra people - a few of whom appear in Grayden's film and most of whom also have close family who appear in it were gathered in 2008 and 2009 during a 're-documentation' project of historical films and photographs conducted by Pamela McGrath. ${ }^{1}$ Supporting ethnographic observations and opinion offered by David Brooks has been gathered during his time working as an anthropologist for Ngaanyatjarra Council, a career that spans over two decades. ${ }^{2}$ We begin with a brief account of the 'Warburton controversy' of 50 years ago, providing a description of Their Darkest Hour and its circulation and reception. We then analyse what the film and associated texts suggested about the quality of remote Aboriginal lives, discuss how they are received and valued by yarnang $u^{3}$ families today, and examine why their ongoing use by others is at times highly problematic.

1 This fieldwork was conducted as part of Pamela McGrath's doctoral thesis, 'Hard looking: an historical ethnography of the filming and photography of Aboriginal families in the Ngaanyatjarra Lands, Western Australia'.

2 David Brooks is currently completing a doctoral thesis on the changing social organisation of Ngaanyatjarra people.

3 Ngaanyatjarra term for Aboriginal people. 


\section{The 'Warburton Range controversy' and the making of Their Darkest Hour}

The 'Warburton Range controversy' was a national public debate about the health and welfare of desert Aboriginal people living in and around the Warburton mission, the Rawlinson Range and the Blackstone Range in the Central Aborigines Reserve ('the Reserve'). ${ }^{4}$ The controversy had its provenance in a protracted argument between state and commonwealth governments, anthropologists and activists about how best to manage the fate of those Aboriginal people whose remote existences were set to collide with a series of major national defence projects that began in the late 1940s. ${ }^{5}$ Ngaanyatjarra country (Map 1) lay directly under the flight path of the Blue-Streak (non-atomic) missiles being tested by the Woomera Research Establishment (WRE). In 1956, an area of Ngaanyatjarra country in the Rawlinson Range near the present day community of Warakurna had been excised from the Reserve and hosted a weather station that fed meteorological data back to the WRE. Giles weather station, as this little outpost came to be known, was the first permanent colonial occupation in the area of the Rawlinson Range and at the time a number of yarnangu families continued to live in the area relatively independently of the Warburton mission. ${ }^{6}$

In February 1957 William Grayden, a war veteran from the conservative side of politics, and Victorian Aboriginal activist, church pastor and football star Doug Nicholls, made a journey together from Perth into Ngaanyatjarra country. They were on a mission to prove that Aboriginal residents of the Reserve were struggling to survive in an era of increasing defence and mining activity. Determined to provide tangible evidence, Grayden took with him a Bell and Howell 16mm film camera. The images Grayden shot on this trip form the basis of Their Darkest Hour and were also published in his book Adam and Atoms (1957). The film is one of the earliest examples of activist documentary in Australia, and in the sphere of Indigenous social justice arguably one of the more successful. Shown at public meetings in churches, town halls and activist conferences across the nation for years afterwards, the film variously shocked and enraged audiences. It has been attributed with fuelling a wave of public support for the Aboriginal rights movement in New South Wales and Victoria in the late 1950s, support that eventually led to the successful 1967 national 'citizenship' referendum to amend

4 Over a period of two years in the early 1920s the Western Australian, South Australian and Commonwealth governments gazetted large areas of land adjacent to the common borders of South Australia, Western Australia and the Northern Territory as Aboriginal reserves. Together these formed the Central Aborigines Reserve, totalling an area of around 170,000 square kilometres. The Reserve was intended to protect Aboriginal people residing in the area from the detrimental influences of frontier contact with settler society. Entry into the Reserve required permission from the relevant government authority (Gara 2003: 19).

5 This history of these developments and the activism surrounding them has been well documented by, among others, Morton 1989; Kerin 2004; Davenport et al 2005.

6 Members of these families would sometimes travel into Warburton or Ernabella missions to attend ceremonies or trade dingo scalps for food goods. 'Dogging' (trading scalps) was also facilitated by the Native Patrol Officers who worked around the Rawlinsons and who would trade scalps at the missions on their behalf. By the late 1950s the children of some Rawlinson families were also attending school at the mission. 
clauses of the Australian Constitution concerning Aboriginal people. ${ }^{7}$ The book, Adam and Atoms (1957) included a number of black and white photographs taken by Grayden during the 1957 trip, but also others taken during an earlier expedition to Ngaanyatjarra country four years previously.

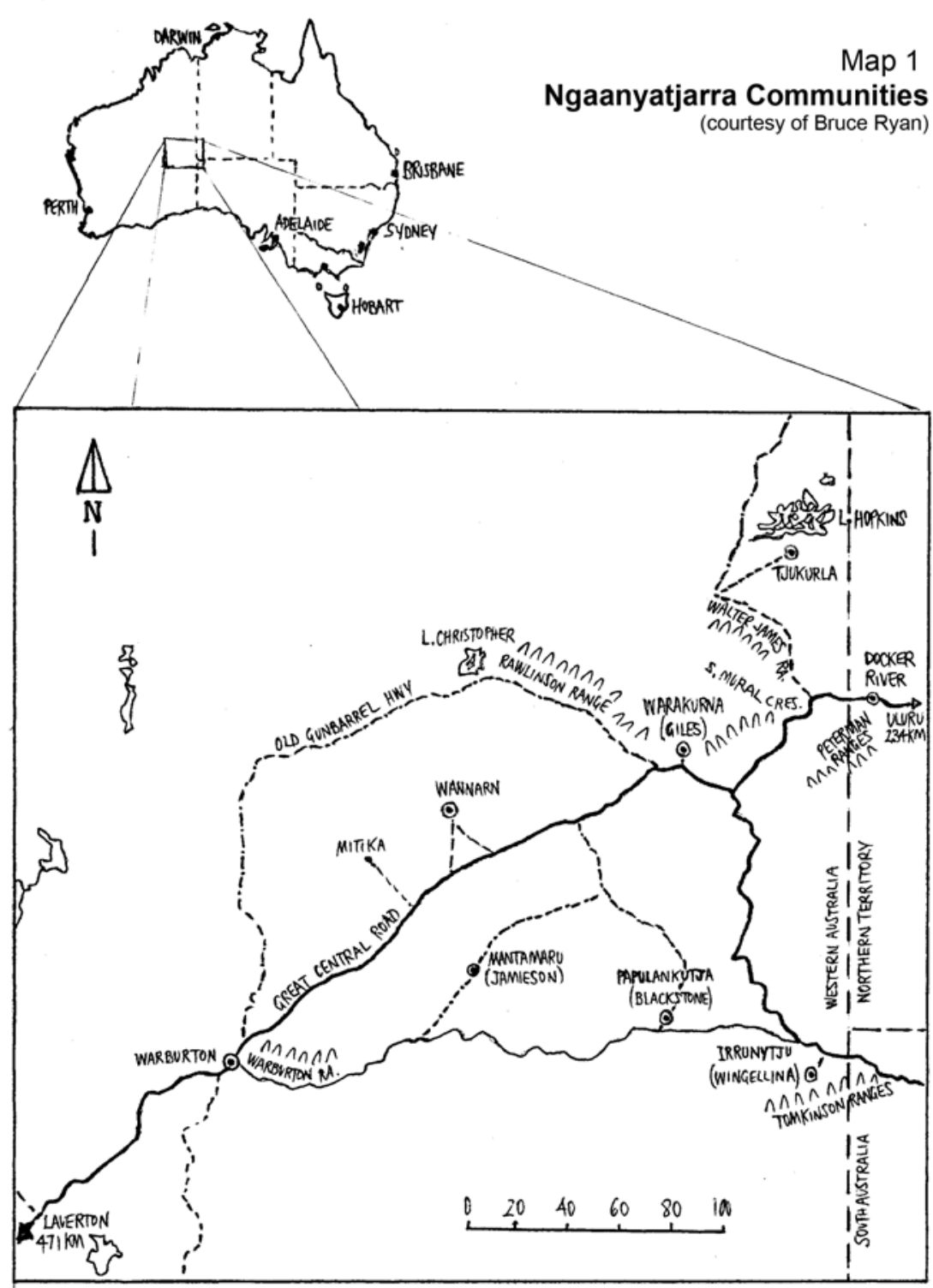

Map 1. Ngaanyatjarra communities.

Source: Courtesy of Bruce Ryan.

7 See for example Clark 1965; Victorian Aboriginal Advancement League 1985; Horner 2004; Taffe 2005; Clark 2008. 
Grayden is a far more complex political figure than has previously been acknowledged in histories of the Warburton controversy. ${ }^{8}$ It was he, not Nicholls, who was the driving force behind the advocacy on behalf of desert Aborigines. His advocacy was inspired by his participation in a 1953 expedition to the Rawlinson Range in search the remains of the explorer Ludwig Leichhardt (and possibly the infamous gold reef of ill-fated prospector Lasseter). According to Grayden, what he found instead was a contemporary tragedy of suffering and neglect among the Aboriginal people living there that moved him to radically alter his personal and political priorities: 'To think that people could survive under those conditions was extraordinary. They were very deprived. I realised there was such a tremendous amount to do for the Aborigines of Western Australia'. ${ }^{9}$ When Grayden returned to Perth he launched a campaign to draw attention to their plight. ${ }^{10}$

At the time of his 1953 expedition, Grayden's political career was already well underway. He had entered the Western Australian Legislative Assembly in 1947 at the age of 27 as a member of the Liberal Party. He held the seat until 1949, when he entered Federal Parliament for the Perth electorate of Swan. He lost his seat in 1954, and re-entered state politics in 1956. He subsequently held the seat of South Perth for 26 years as an Independent Liberal, and later as a Liberal, for 37 years until his retirement in $1993 .{ }^{11}$ Early in his career Grayden had earned a reputation as a 'young rebel' of Western Australian politics, infamously unafraid of courting publicity to further his political aims. ${ }^{12}$ While known for his humanitarian interest in Aboriginal issues, his financial interest in mining was also widely reported, not always favourably. ${ }^{13}$

8 Later in his career Grayden's reputation as a supporter of Aboriginal people was overshadowed by his involvement in Noonkanbah affair in the 1980s. In 1981 the Federal government attempted to restrict the international release of an activist film critical of the Western Australian government's management of the Noonkanbah affair, On Sacred Ground (1981) over concerns that it would damage Australia's international image. The film includes an 'arresting' scene showing members of the Noonkanbah Aboriginal community listening to a taped message from Grayden, then Minister for Education and Cultural Affairs under Premier Sir Charles Court. Grayden reportedly speaks to them 'in tones usually reserved for addressing school children'. More importantly, he refused to recognise the sacred sites that community members asserted would be impacted by the mining. It is these events, rather than his advocacy at the time of the Warburton controversy, for which he is most remembered in histories of Aboriginal activism in Western Australia. See Hawke and Gallagher 1989: 170.

9 Ferrell 1989: 45, 138.

10 'Grayden sees misery in hungry land', West Australian, 18 August 1953; 'Bush natives don't laugh on cold nights', West Australian, 3 October 1953.

11 Jamieson 1986: 1-4.

12 'The young rebel: Bill Grayden MP believes in keeping himself in the public eye - at all times', People, 1 May 1957: 35.

13 Accompanying Grayden on his 1953 expedition was the owner of a gold mine near the town of Laverton, Stan Bridgeman. Grayden himself admitted to having researched the location of Lasseter's Rawlinson Range peggings prior to departing on the expedition, and while in the area having 'a cursory look' around. There was controversy in the press about this at the time, with suggestions that the search for Leichardt was futile and that Grayden was inappropriately drawing on government funds to finance it. People, 1 May 1957: 35; Grayden 2002: 8; Ferrell 1989: 121. 
Shortly after his re-election in 1956, Grayden began to lobby hard for an investigation into the possible effects of proposed atomic weapons testing at Maralinga on 'nomadic natives' in the Reserve, and made efforts to thwart a proposal to remove children from the Warburton mission to attend school in Laverton. ${ }^{14}$ His efforts were encouraged by a correspondence with activist and medical doctor Charles Duguid, who had been involved in protests against the proposed 'rocket range' in the $1940 \mathrm{~s} .{ }^{15}$ A parliamentary select committee was subsequently established to investigate Aboriginal welfare in the Reserve. It was comprised of representatives from all three political parties represented in the state parliament at the time: Labor, the Liberal and Country League, and the Democratic and Country League, as well as Grayden himself. ${ }^{16}$ In November 1956 the Select Committee spent a week in the area of Laverton and the Warburton mission interviewing various non-Aboriginal locals including pastoralists, schoolteachers, missionaries and police. ${ }^{17}$ While at Warburton they saw a group of Rawlinson Range people who had only days before walked into the mission from the north near Mitika, a rock hole approximately 100 kilometres north of Warburton mission. They would come to be known as the 'Famous Forty' for the publicity they subsequently received. Some of them had never been into the mission before, and many were reported to be 'in a starving condition and were extremely emaciated' ${ }^{18}$

The Report of the Select Committee Appointed to Inquire into Native Welfare Conditions in the Laverton-Warburton Range Area ('the Select Committee Report') tabled in parliament in December 1956 detailed numerous hardships faced by many Aboriginal people in the area: a lack of adequate food and water supplies; high incidents of diseases such as yaws and trachoma; frequent accidents such as burns from rolling into sleeping fires; unnecessary mortality due to preventable illnesses; and a lack of local opportunities for education and employment. ${ }^{19}$ The Commonwealth government's appropriation of land for the establishment of the Giles weather station was identified as an issue of great concern. The Report recommended an immediate increase of medical resources to missions servicing the area; the cessation of the policy of removal of children; the provision of more frequent and reliable water sources; the development of an Aboriginal-based pastoral and agricultural industry; and a relaxing of the 'isolationist' approach to the management of the Reserve. ${ }^{20}$ Four days before Christmas at ten to four in the morning, the recommendations of the Select Committee Report were accepted by the Western Australian state legislature.

At first the Select Committee Report received very little attention in either the local or national press. It was only after articles highlighting the worst of

14 ABC News Service, 16 August 1956, in possession of William Grayden, Perth.

15 Letters from Duguid to Grayden, 1957-58, in possession of William Grayden, Perth. See Kerin 2004 for more information on Duguid's activism.

16 Grayden 1957: 6.

17 Grayden 1957: 7.

18 Grayden 1957: 22.

19 Grayden 1957: 36-38.

20 Grayden 1957: 16, 41. 
the problems identified by the Select Committee appeared in eastern states socialist newspapers such as The Tribune, that mainstream media sat up and took notice. ${ }^{21}$ Journalist Rupert Murdoch, who at the time ran both The News in Adelaide and the Sunday Times in Perth, filed editorials criticising the findings of the Select Committee as exaggerated and misleading. Grayden and his supporters responded with articles of their own. ${ }^{22}$ The controversy escalated, and in early February 1957 Murdoch chartered a flight to investigate conditions on the Reserve first hand. ${ }^{23}$ He spent a day in Giles, and while there interviewed Robert Macaulay, a young anthropology graduate from Sydney who had only months before been appointed to the position of WRE Native Patrol Officer based at Giles. Macaulay confirmed for Murdoch that 'the general health of the Rawlinson people appeared extremely sound judged by Aboriginal standards' ${ }^{24}$ Murdoch subsequently ran a series of articles claiming he had spoken to a number of local Aboriginal people, none of whom agreed with the findings of the Select Committee Report and that these people were generally in fine shape and had profited much from the controlled intrusion of the white man into this area'. ${ }^{25}$ A barrage of articles and editorials in other papers followed, with accusations of exaggeration, manipulation and ignorance coming from all sides. ${ }^{26}$ With the controversy raging and the reliability of the Select Committee Report publicly undermined, Western Australian Minister for Native Affairs, John Brady, resolved to personally survey the conditions on the Reserve. On 19 February 1957, he set out for Laverton from Kalgoorlie accompanied by two Department of Native Welfare (DNW) District Officers McLarty and Harman, and a policeman Sergeant Anderson. It was the first time that officers from the DNW had ventured beyond the Warburton mission. Two journalists from the Daily News and the West Australian joined them. ${ }^{27}$ Travelling with Brady's convoy was a party of five medical professionals who were to conduct a survey of Aboriginal people's health.

Frustrated with growing public scepticism about the conditions he reported on the Reserve, Grayden decided to trail Brady's official government expedition with one of his own. Returning to the Reserve for the second time in three

21 Seefor example, 'Worst life in the world', The Sun, 12 January 1957; 'Conditions of W.A. Aborigines "worst in world"', Sydney Morning Herald, 12 January 1957; 'Shock report on Aborigines', The News (Adelaide), 11 January 1957; 'Native scandal in WA', The Herald (Melbourne), 15 January 1957.

22 See for example 'Proof of native plight claimed', The Advertiser, 16 January 1957; 'Babies killed so others may live', Daily News, 16 January 1957. In possession of P McGrath, Canberra.

23 Grayden 1957: 52.

24 'Rawlinson Natives never better off', Sunday Times [1957]. In possession of W Grayden, Perth.

25 'I had no alternative - I saw twice as many natives', Murdoch in The West, 12 February 1957.

26 See for example 'Warburton missioner backs Grayden', HE Green in The West, 11 February 1957; 'Hardship comes naturally to outback nomads', The West, 17 February 1957; 'We must stop this misery and suffering', Grayden in The West, 19 February 1957; 'MLA: Natives' lot worse than we said', [Unknown], 16 January 1957. In possession of W Grayden, Perth.

27 Central Board of Health, State Records Office of Western Australia [hereafter SROWA], Series 268, Item 1957/0283: 77. The anthropologists Ronald and Catherine Berndt, at the time employed at the newly established Department of Anthropology at the University of Western Australia, were asked to report on the situation and visited Warburton mission shortly afterwards. A team of medical experts followed soon afterwards. 
months, this time Grayden asked Doug Nicholls and Select Committee member Stan Lapham to join him. ${ }^{28}$ Nicholls' interest in the Aboriginal people of the Central Aborigines Reserve was not new. In 1946 he had joined Charles Duguid and anthropologist Donald Thomson to lobby against the establishment of the long-range missile testing programme. Their actions had resulted in a personal assurance from the Governor General at the time that Aboriginal people living in the area would be given 'every attention and protection' from the impacts of national defence projects. ${ }^{29}$ Perhaps fearing a broken promise, Nicholls accepted Grayden's invitation and hastily packed his bags for Perth. Only weeks before he had been in the audience of a public screening of a film showing the 'squalor' of Aboriginal camps in the Northern Territory settlement of Aileron. ${ }^{30}$

In total these two expeditions constituted an unusually large influx of visitors into the Reserve and many yarnangu were reportedly aware of their presence, if not their purpose, as they journeyed through the area. Both the Ministerial and Grayden's parties arrived at the Warburton mission from Laverton on 23 February. Nicholls was invited to assist with the Sunday church service the following day. Native Patrol Officer Walter MacDougall arrived shortly after, and the next day escorted Brady's party on a two-day inspection of the surrounding area. The entire convoy followed. Travelling in the height of summer and likely in excessive heat, dust and wind, the road-train of bureaucrats, doctors, journalists and politicians in jeeps and trucks inspected a number of rock holes near Warburton with the assistance of Aboriginal men resident at the mission. They came across a large group people camped at Mitika, among them families from the Rawlinson Range and some of the 'Famous 40' whose condition had caused the Select Committee members so much concern three months earlier when they had arrived at the mission in poor condition. ${ }^{31}$ They had recently left the mission and were returning home. According to DNW District Officer McLarty, they were already planning to backtrack to the mission because the resources at Mitika were close to depletion. In his words, the group were not, however, 'short of water' and 'not seriously short of food', and they were fit to walk to Warburton unassisted. Another group had just left Mitika to walk north to Giles, led by Grayden's guide during his 1953 expedition, Mitawali Wally Porter. $^{32}$

McLarty's report contrasts starkly to the situation as reported by Select Committee member Lapham, who suggested that among their numbers there were individuals who were too ill and malnourished to hunt, let alone make their own way back to the mission. ${ }^{33}$ Grayden was horrified and filmed the people they met at Mitika, the resulting images proving to be some of the most

28 Grayden's wife also accompanied the party.

29 Clark 1965: 83.

30 'They saw natives in death march', The Sun, 18 January 1957.

31 Patrol Report No 2 of 56/57, Central District, SROWA, Series 268, Item 1957/0283: 73.

32 Lapham to Commissioner of Native Welfare, Middleton, 14 March 1957. In possession of David Brooks, Canberra.

33 Lapham to Commissioner of Native Welfare, Middleton, 14 March 1957. In possession of David Brooks, Canberra. 
distressing for audiences who later saw Their Darkest Hour and read Adam and Atoms. McLarty, who was present during filming at Mitika, told of how Grayden selected 'any subject which might be used to support his published statements' and avoided 'anything which would not'. Grayden reportedly went to such extremes that Minister Brady 'was obliged to remonstrate with him', while McLarty and Assistant District Officer John Harman 'withdrew in anger and disgust'.$^{34}$

The convoy returned to Warburton, and a few days later made their way east to Blackstone mining camp. There they met a group of approximately 50 adults and children, many from Warburton, who had walked to Blackstone to visit family while the mission was closed for the 'Christmas time' holiday. Among their numbers were also members of families who had 'country' in the immediate area and who regularly spent time there. Lapham stated that the group were there in order to find work because they were otherwise starving; McLarty suggested the migration east was in keeping with traditional seasonal migrations. McLarty's report contains no details of food shortages, and he notes that three women and two men among the people camped at Blackstone took the opportunity to exchange dingo scalps for trade goods. ${ }^{35}$ Lapham, on the other hand, recorded that the group was without adequate food and were waiting for rain before returning to Warburton. ${ }^{36}$ Grayden and Nicholls purchased basic foodstuffs for the families from the nearby mining camp and filmed while Nicholls distributed them to families. During this exchange Nicholls spoke to Stewart Davies, a yarnangu man who often acted as an intermediary between his people and various incomers, but there is no record about what was said between them (Fig 1).

While at Blackstone, Grayden also filmed an old man by the name of Mr Jacky Forbes. Mr Forbes had lost his foot following a spear fight with his brother George many years before. He remained mobile and living semi-independently of the mission using a crutch and an enormous bandage that acted as an artificial foot. He was very shy about his disability and reportedly would insist on complete privacy whenever the bandage was removed. Philip West was a good friend of Mr Forbes and was with him when Grayden asked to film his injury. Mr Forbes agreed but insisted that they do so in the bush away from the camp so that no one else would see. ${ }^{37}$ Grayden also filmed his blind brother, George. ${ }^{38}$ Grayden's

34 Patrol Report No 2 of 56/57, Central District, SROWA, Series 268, Item 1957/0283: 73.

35 Patrol Report No 2 of 56/57, Central District, SROWA, Series 268, Item 1957/0283: 71. At the time dingo scalps attracted a bounty of around 18 shillings, and many yarnangu would trade scalps for basic goods at Warburton or Ernabella missions when the opportunity presented itself. Department of Native Welfare 1956-1958, Macaulay Patrol Report No 1, 19 November 1956, SROWA, Series 2030, Item 1956/0280: 2.

36 Lapham to Commissioner of Native Welfare, Middleton, 14 March 1957. In possession of David Brooks, Canberra.

37 West, P, pers comm 20 May 2008. When Mr West watched Manslaughter for the first time in 2008, he expressed surprise that he too was not featured in the film as he had helped Mr Forbes unwrap his foot so Grayden could film him.

38 Lane, F, pers comm 8 May 2009. The story of how these two brothers came to be lame and blind is well known among family and older yarnangu. After Jacky lost his foot after a spear fight with his brother George, he retaliated by rubbing a poisonous plant in his brother's eyes, permanently blinding him. 
filming activities did not go unnoticed. The journalists and the manager of the nickel mine later reported to the Deputy Director of the Bureau of Meteorology that Grayden and Nicholls had 'lined up the cameras and then allowed the natives to scramble for supplies. ${ }^{39}$

At this point in the journey the convoy split. Brady and the medical party, along with the two reporters, travelled onto Giles leaving Grayden and Nicholls at Blackstone. A handful of Rawlinson families camped at Warupuyu, a soak and traditional camping site located at a 'gap' in the ranges a few kilometres from Giles, were about to leave the area, but were convinced to stay by Macaulay in order to receive health checks from the visiting medical party. Macaulay carted water to them at their camp so they had sufficient to stay a few more days. By the end of the week more people had arrived, possibly in preparation for a ceremony, but possibly hoping to meet the expedition who they knew had been travelling in that direction. ${ }^{40}$ Among them were the group that Mitawali Porter had led from Mitika less than a week before. ${ }^{41}$ They had been travelling by foot and had walked over 100 kilometres. Grayden arrived at Giles a day or two after Brady had left, and camped overnight. He spent time filming around the station and at the Aboriginal camp at Warupuyu, and also filmed Nicholls examining a group of children of various ages, and interacting with a group of adults as they sat quietly in the shade of a small grove of trees.

Grayden's party left to return to Warburton the following day. When they got there they were told that a man's body had been found by a dried up water hole near Mitika. They travelled with Sgt Anderson and Ngaanyatjarra man Don Richards to investigate. At the time the identity of the man was unknown by Grayden, the missionaries or the police, but local yarnangu had their suspicions about who it was and why he died there. That the identity of the man and the cause of his death were unknown mattered little to Grayden. He got out his camera and filmed while the others dug a shallow grave and buried the body. Upon their return to Perth, Grayden hastily processed the footage accumulated during the trip, and he and Nicholls wrote a script for a spoken commentary. The result was Their Darkest Hour. In the following months he had also self-published Adam and Atoms, and the book was in circulation by May $1957 .{ }^{42}$

39 Commonwealth Bureau of Meteorology Regional Office Western Australia, National Archives of Australia [hereafter NAA], Series PP470/1, Item 761.

40 Patrol Report No 2 of 56/57, Central District, SROWA, Series 268, Item 1957/0283: 68.

41 Lapham to Commissioner of Native Welfare, Middleton, 14 March 1957. In possession of David Brooks, Canberra.

42 Grayden continued to distribute copies of the book for some years to come. During his February 1959 campaign for the seat of Swan, he glued a letter into the front cover before delivery. It stated that that, 'I offer you this book to prove to you that where injustice is concerned, I do not spare myself in time or effort'. In possession of P McGrath, Canberra. 


\section{Images of Their Darkest Hour}

What does Grayden's film look like? Filmed in grainy, contrasty colour, Their Darkest Hour runs for just over 20 minutes. The film shows images of the Aboriginal people Grayden and Nicholls met at Laverton, Warburton mission, Blackstone, Giles and Mitika rock hole in 1957. With sync-sound technology still some years away, the footage was recorded without a soundtrack and a prerecorded voice-over was not produced until it was screened in a local cinema and on television later that year. When shown at public meetings, the commentary drafted by Grayden and Nicholls was read aloud by an invited speaker. ${ }^{43}$ The film was never intended for theatrical release and therefore has no opening title or production credits. No Ngaanyatjarra people are named in the narration or in Adam and Atoms, and no biographical details other than brief explanations of people's ailments are included.

Their Darkest Hour begins with an image of the town of Laverton, the last settlement before entering the Reserve from the west. The first Aboriginal person the audience sees is an old, blind woman in a camp at the Laverton Aboriginal reserve. She wears torn and dirty clothing and is sitting on the ground with her dog. She hides her face, avoiding looking at the camera. She can be seen saying something, but we are not told what. The narrator tells us, 'This lonely old woman is blind.'

We see scenes of a truck driving along a dirt road and traversing sand dunes as the party journeys towards the Warburton mission. There are shots of the carcasses of dead animals and a circling bird of prey. The scenes of the mission show a number of Aboriginal children in clean clothes engaged in various activities: smiling and laughing, playing in a dusty yard, drinking goats' milk from a tin. The narrator says, 'Mr Wade [the missionary] has a small cauliflower patch. The children love the cauliflower stalks and eat them in the same way as our children eat apples.' A number of neatly dressed Aboriginal adults wander past a mission house. A group of people queue at the door of the one-room hospital, waiting to see the nurse.

A montage of images of groups of people sitting along the mission fence follows. They are all in tattered remnants of European clothing. A group of Aboriginal men sit together; they are unsmiling and look directly at the camera, their spears visible on the ground in front of them. A group of women sitting in front of wiltja (shelters) smile and laugh as a small child in a cardigan plays with a billycan. One woman shows off her wedding ring. Other women avoid looking at the camera, turning their heads away. We see a close-up of a burn on a baby's leg, and a woman with a wound on her arm that the narrator tells us is a symptom of the leprosy-like disease yaws. The film cuts to a shot of a thin, naked child standing alone in front a small building. He is not smiling and avoids looking directly at the camera. He twists his fingers. The narrator tells us: 'Some of these

43 Horner 2004: 25. 
natives were with a party of 43 that reached the Mission in a starving condition a few weeks before the film was taken. Three died after reaching the Mission. It is not known how many died on the journey in from the desert.'

The action moves to the mining camp of Blackstone. Doug Nicholls is seen handing out tins of food to a large group of people who are gathered around a truck (Fig 1). The narrator comments, 'At Blackstone we find 50 natives who are without food. The mining company is not permitted to provide food or medical attention for them.' Nicholls talks to members of the group, including Stewart Davies, but we do not know what they say. The film cuts to the image of Mr Forbes walking with a crutch, one foot heavily bandaged such that it resembles an elephant's foot. The next shot shows a close-up of the bandage. The next one is of his unbandaged leg, revealing that he is missing a foot. The camera lingers on his naked stump while the narrator tells us he has recently walked to Blackstone from Warburton, a distance of almost 200 kilometres. There is a shot of another old Aboriginal man, holding onto a stick, being led by an Aboriginal woman away into the bush. The narration continues: 'This is George, an old blind native who set out last Christmas with two other blind women to walk 600 miles to Ernabella Mission in South Australia'.

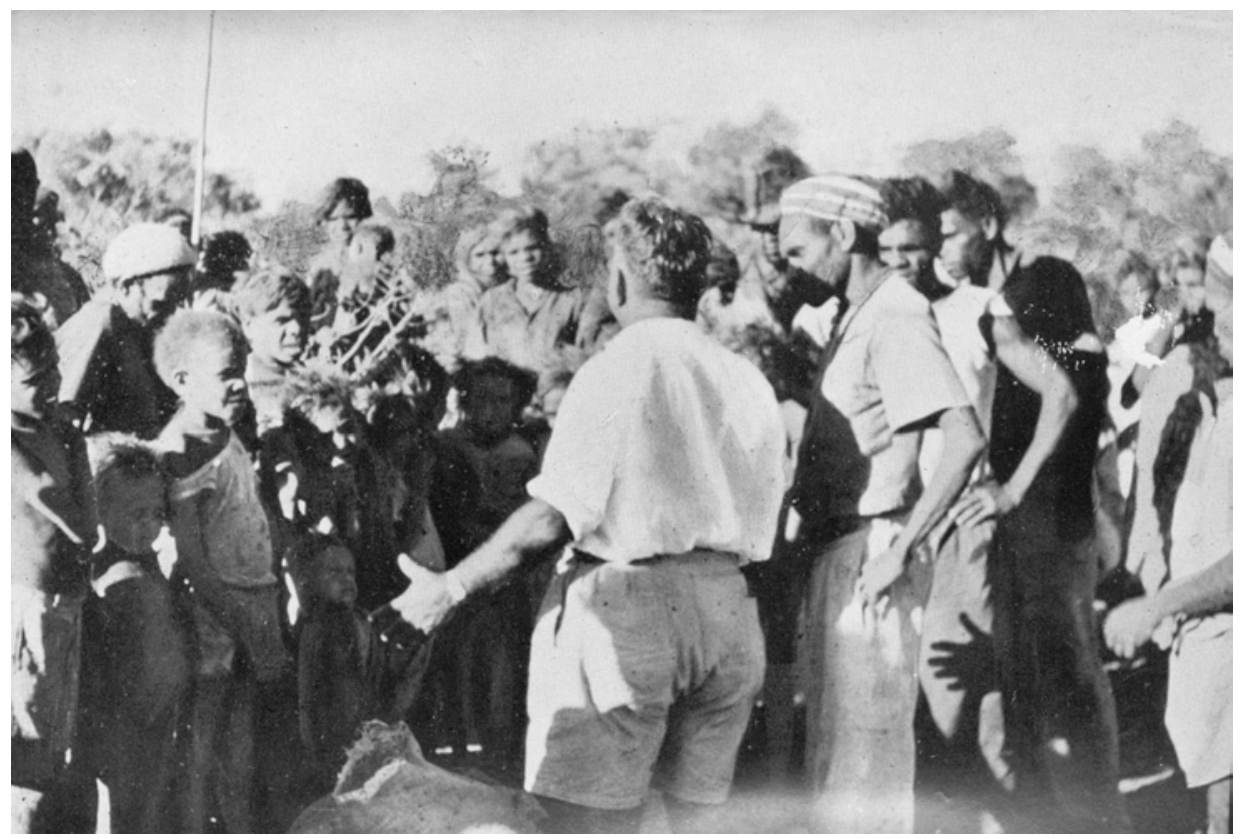

Fig 1. Doug Nicholls addresses a group of people at Blackstone, February 1957. Footage of this meeting appears in Their Darkest Hour. The Aboriginal man in the knitted hat standing on his right is Stewart Davies. On the far left Mr Forbes can be seen standing with his head bowed, also wearing a knitted hat and holding the stick he used for a crutch.

Source: Grayden 1957: 96. 
The action then moves to Giles weather station in the Rawlinson Range, where we are told: 'the natives are forced to live in close contact with the whites'. The film shows a group of unsmiling Aboriginal people in tattered clothing sitting together in the shade of some small trees. A group of seven children aged between approximately four and eight years of age are shown standing in a line in front of a yellow truck, likely that of the Native Patrol Officer Robert Macaulay. The film cuts to a close-up of the same group of children, focusing on their torsos:

Some of the children are from the Mission Home. Each year the Mission goes into recess for three months. Then the children who for the remaining months of the year have been clothed and fed on White food are returned to their parents and all have to fend for themselves.

Out of sequence with actual events, the film then shows Grayden's party travelling to Mitika. Again the audience sees a montage of images of Aboriginal people, many children. There is a close-up shot of a boy approximately seven years old, standing on his own. His stomach is extremely distended and he looks blankly at the camera. We are told: 'There are 43 natives camped at the hole when we reach it, 19 of who are children. Almost all the children are clearly suffering from malnutrition'. The camera films Nicholls providing water to two very skinny young boys whose stomachs are engorged with the water they hastily drink. Another little boy chews on a kangaroo bone that looks uncooked. A forth looks up into the camera, his eyes full of flies. The narrator asks: 'These people are trained hunters. Would they be in this condition if food and water is plentiful on the Reserve, as some people have stated?'

The next scene shows Nicholls helping a woman with a sick baby into the back of the truck:

The natives said that the mother's milk had dried up and they feared the baby would die that night. The mother was so weak that she had to be assisted to her feet. We took her back to the Mission in our truck.

The film ends with the discovery and burial of the remains of the man found at the dry waterhole near Mitika. We see close-ups of his skull and torso from a number of different angles, and watch while three men bury him in a shallow grave. The final words of the spoken narrative are: 'The body is buried. No cairn marks the spot. Human life has little value on the Warburton Reserve'.

\section{Circulating Their Darkest Hour}

From what we know about the reception of Their Darkest Hour and Adam and Atoms, audiences found these images confronting. They were intended to be. Grayden's choice of framing reflected his firm belief that audiences needed to be shocked into recognising that Aboriginal people were suffering terribly and the citizens of Australia had a responsibility to do something about it. In his mind the strength of his concern justified the intrusion of his camera in circumstances where filming might otherwise be considered inappropriate, for example the 
filming of Mr Forbes' foot without its bandage, or the filming of the dead man. For Nicholls as well these were deeply disturbing scenes and his experiences reportedly had a profound impact on his personal and political world view: ${ }^{44}$

Everywhere we went they pleaded for food and water, it is terrible. I wish I had not gone to the Warburton Ranges. I wish I hadn't seen the pitiable squalor, the sights of my people starving - the most shocking sights I have ever seen. Never, never can I forget. ${ }^{45}$

The film was first screened in March 1957 at the Central Methodist Mission Hall in Perth, with Grayden reading the accompanying commentary. ${ }^{46}$ Nicholls took a copy of the film with him when he headed home to Melbourne later that week. Soon after he screened it at a meeting of individuals concerned about Aboriginal welfare, in part inspiring their decision to form the Aborigines Advancement League. ${ }^{47}$ Other copies were made and widely distributed through the networks of organisations such as the Federal Council of Aboriginal Advancement and was screened at churches, trade unions and film groups across the country. ${ }^{48}$ Nicholls spoke at many of these early meetings. Grayden organised for a six week screening during April and May 1957 at the Theatrette Mayfair in Perth, claiming that it generated much interest, doubling usual attendances. ${ }^{49}$ The film was also shown on television in Melbourne and Sydney in May, inspiring a wave of correspondence to newspapers and government and generating considerable donations to a fund for the welfare of the Warburton Aborigines. ${ }^{50}$

Their Darkest Hour had a dramatic impact on many who saw it, among them urban Aboriginal people from New South Wales and Victoria. Many people who saw it subsequently wrote letters to bureaucrats and politicians, including Prime Minister Menzies, expressing how the film made them feel 'thoroughly disgusted', 'shocked' and 'shamed', and experienced 'violent feelings of revulsion', and demanding something be done about it. ${ }^{51}$ One journalist described it as 'the most horrible film made in Australia' ${ }^{\prime}{ }^{2}$ others compared it to images of the Nazi death camp at Bergen-Belsen ${ }^{53}$ and films from Japanese prisoner of war camps. ${ }^{54}$ Its

44 Clark 1965: 183.

45 Nicholls in Simmons 1957: np.

46 Clark 1965: 179.

47 Attwood 2003: 151; Horner 1982: 4; McGrath 2004: 62; GRAYDEN_FILM/VIDEO_01 LV0356.

48 For example: the Narrogin Native Welfare Association, Western Australia (June 1957); the Labor Council of New South Wales (June 1957); the Melbourne University Aboriginal Scholarships Committee (July 1957); a congregational church in Victoria Park, Perth (August 1957); the Rosanna Baptist Church, Victoria (September 1957); the Sheffield Aboriginal Advancement League in Tasmania (June 1958); and the Ballarat Aboriginal Advancement League (January 1959), SROWA, Series 2030, Item 1957/0384. It was also screened in Walgett in August 1957 (Curthoys 2002: 86).

49 Grayden 1957: 164.

50 Simmons 1957: np; Horner 2004: 25. Among these were donations of stud goats and an offer to adopt two children. Department of Native Welfare, SROWA, Series 2030, Item 1957/0040.

51 Department of Native Welfare, SROWA, Series 2030, Item 1957/0040, 1957/0384.

52 The Mercury, 28 March 1957.

53 M Kibel to Prime Minister Menzies, 2 May 1957, Department of Territories, NAA, Series A452, Item 1957/245.

54 The Advocate, 25 April 1957. 
reception in the press was monitored by state and Commonwealth government agencies such as the Department of Native Welfare in Perth and Australian Security Intelligence Organisation in Canberra. ${ }^{55}$ The Warburton controversy received attention internationally including from the Malaysian, New Zealand and English press. ${ }^{56}$ The Prime Minister's Office were concerned enough about the potential negative impact on Australia's international reputation to issue a press release to all diplomatic posts stating that 'the film is not designed to give a balanced picture of the circumstances of aborigines [sic] either in Australia, in general, or in the area to which the film is particularly related' ${ }^{57}$

It is impossible to estimate the extent of the film's circulation in terms of viewing numbers. Data indicating the number and size of meetings at which it was screened are non-existent. But there is evidence that the film continued to circulate widely into the early 1960s. Aboriginal activist Faith Bandler showed the film to Black American singer, actor and civil rights activist Paul Robeson during a visit to Australia in the early 1960s. His response was one that Bandler would never forget: 'Tears came to his eyes and when the film finished he stood up and he pulled his cap off and he threw it in his rage on the floor' ${ }^{58}$ Its screening on television in 1957, only a year after the technology was introduced to Australia, is significant. Peters-Little suggests television was responsible for breaking 'the invisibility of Aborigines to mainstream white Australia', ${ }^{59}$ and the images of Their Darkest Hour were some of the first to be aired. As far as we know, however, the film was not screened at the Warburton mission or anywhere else in the Ngaanyatjarra Lands until 50 years later.

Grayden's images were crucial evidence for his advocacy, ${ }^{60}$ and their injection into the public debate of the Warburton controversy resulted in an escalation of the use and abuse of photographs and films of Aboriginal people by others as well. Articles supportive of Grayden's position were often illustrated with photographs (not always taken by Grayden) of rake thin children with distended abdomens, carrying headlines such as 'The swollen stomach of malnutrition'. ${ }^{61}$ Many of the countering articles by Murdoch and his journalists were illustrated with photographs that were as equally reassuring as Grayden's were shocking, such as one of smiling Aboriginal children swimming in a waterhole near Warburton mission. ${ }^{62}$ None of the scores of newspaper articles that used such

55 For example, ASIO Central Office, NAA, Series A6122/44, Items 1524 and 1525; Department of Territories, NAA, Series A452, Item 1957/245.

56 ASIO Central Office, NAA, Series A6122/44, Item 1524: np; Department of Native Welfare, SROWA, Series 2030, Item 1957/0384: 119; 'Atomic bomb may save the Aborigine: plight begins to prick the Australian conscience', The Manchester Guardian, 10 February 1957, SROWA, Series 2030, Item 1957/0040: 125.

57 ASIO Central Office, NAA, Series A6122/44, Item 1524.

58 Hughes 2009: np.

59 Peters-Little 2002: 10.

60 In an article in The West Australian, a member of the Select Committee member claimed 'we can back up our report with photographs of the poor creatures'. 'Aborigines eat poison bait', West Australian, 16 January 1957.

61 [Unknown, 1957]. In possession of W Grayden, Perth.

62 'Fun in the waterhole', West Australian, 6 March 1957. 
images, however, identified the Aboriginal people in them or offered yarnangu perspectives on the issue. The issues were usually simplistically reported and the circumstances of semi-nomadic families were confused with the living conditions at the Warburton mission, much to the chagrin of local missionaries and their supporters who were proud of the support they gave with few resources. The missionaries returned fire by publishing images of their own in the United Aborigines Mission monthly newsletter. ${ }^{63}$ Atomic tests at Maralinga (some 800 kilometres to the south-east of Rawlinson Range) were conflated with the WRE long-range missile testing and the establishment of Giles, even in Grayden's mind. ${ }^{64}$ And at least one press article reported, incorrectly, that over 1000 Aborigines had been thrown out of the Reserve to make way for the weather station..$^{65}$ William Bodney, a prominent Nyungar elder from Perth and President of the Coolbaroo League, accused Grayden of misleading the public with his photographs, and demanded that the government 'put a stop to such political adventuring and such similar forms of exploitation of our people and get on with its job of giving us equal rights'. ${ }^{66} \mathrm{~A}$ few years after the events of 1957, Nicholls himself admitted his discomfort with the way yarnangu had been represented: 'The thing became a political football ... It is wrong to make people a football' ${ }^{67}$

Away from the press, many non-Aboriginal people who had worked long-term with Ngaanyatjarra people suggested Grayden's assessment of the extent of people's ill-health was inaccurate. Teams of anthropologists and doctors who visited the area found no widespread disease or starvation and agreed that the situation had been exaggerated. ${ }^{68}$ Macaulay claimed that Grayden's assessment of the conditions of people living in the Rawlinson Range near the weather station was 'so inaccurate and unreliable as to be of little use' ${ }^{69}$ Olive Graham, the nurse at Warburton mission who cared for many of the individuals filmed by Grayden, stated that while it was certainly true that a group of approximately 50 individuals came in from the Rawlinson Range in a 'shocking condition' in November 1956, 'it is very wrong to give the public the impression that the natives in the Laverton-Warburton-Rawlinson area are dying of malnutrition' ${ }^{70}$

63 The monthly newsletter of the United Aborigines Mission of Australia for May 1957 contains a number of photographs of children from the mission that emphasised the care they received there, describing them as 'happy', 'beautiful' and 'worthy of the public spotlight'. United Aborigines Messenger, vol XXV, no 4, 1 May 1957.

64 'Natives die for a weather station', The Sun, 18 January 1957.

65 'We must end this scandal', The Sun, 22 January 1957.

66 Bodney, W [Unknown publisher] 7 February 1957. In possession of W. Grayden, Perth. The Coolbaroo League (1946-1964) was the Aboriginal-controlled community organisation who published Westralian Aborigine newspaper, in which Grayden had previously received positive press about his 1953 expedition to the Rawlinson Range. The League were instrumental in lobbying the Western Australian state government on issues such as the removal of children, citizenship laws, deaths in custody, and civil rights law reform (Kinnane 2007).

67 Clark 1965: 180.

68 Berndt 1957; 'Medical Report on Warburton Natives', SROWA, Series 268, Item 1957/0283; Elphinstone, JJ 1958, 'Report on Health and Nutrition of Native from Rawlinson Range to Lake MacDonald', unpublished report for Department of Public Health Western Australia, Mark Chambers Collection, Perth.

69 Macaulay Patrol Report No 5, 8 March 1958, SROWA, Series 2030, Item 1956/0280.

70 Graham to Middleton, 7 February 1957, SROWA, Series 2030, Item 1957/0384: 104. 


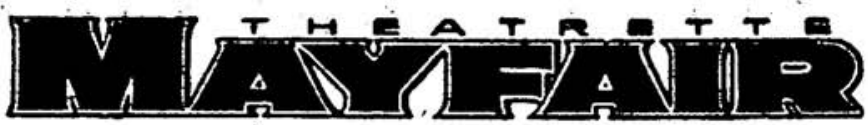

HAY STREET - NEXT TO LEVINSONS

COMMENCING TOMORROW

FOR ONE WEER ONLY

CONTINUOUS SESSIONS FROM 10 A.M.

EXCLUSIVE TO THE "MAYFAIR"

THE PLIGHT

DF DUR ABORIGINAKS

YOU HAVE READ THE CONFLICTING REPORTS - Now Judge FOR YOURSELF

CL5

THE FIIM OF THE

WARBURTON MATIVES
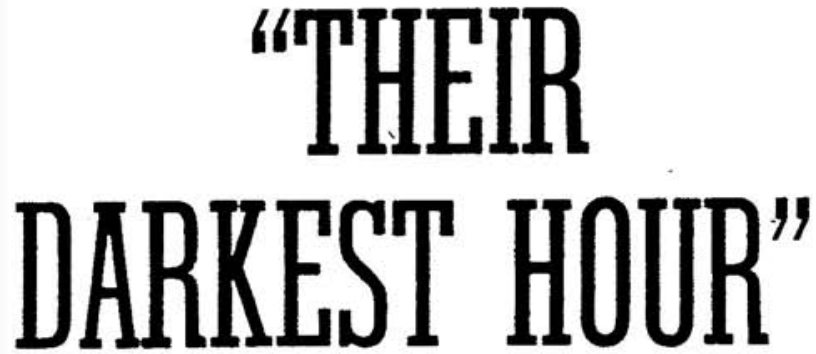

- (NOT SUITABle for ChILDREN)

$\star$ TOM \& JERRY CARTODN

* Shark hUNT- OFF Q'LAND COAST

* TOM EWELL- the football fan

* ACSTRALIAN OVERSEAS NBWS

* RUgbY league cup final

Fig 2. Advertisement for Grayden's Warburton Range film.

Source: Daily News, 23 May 1957. 


\section{The other side of Their Darkest Hour}

The truth of the matter of people's distress and the need for intervention was then, and is now, difficult to determine. Some facts are clear. The poor health of some of those filmed by Grayden was due to a lack of food during a time of intense but highly localised drought, described by Macaulay as 'the culmination of the second worst drought period in the memory of the older Rawlinson natives' ${ }^{71}$ In interviews about this time, older yarnangu acknowledge that the circumstances of the people filmed by Grayden were unusual, but accept it as a part of living life 'in the bush'. This was a 'dry year', a 'hungry time', and while yarnangu appear to have been appreciative of the immediate efforts made by Grayden and Nicholls towards relieving their hunger, the circumstances in which the filmmakers had found them are remembered as highly localised and temporary. The patrol reports of Macaulay for the years 1956 to 1958 confirm this. ${ }^{72}$ More compellingly, the photographs that Macaulay took of many yarnangu families over a nine year period between 1956 and 1964 show that many of the people filmed by Grayden were otherwise fit and continued to live mostly independently of the mission for some years to come. ${ }^{73}$ Many, including Mitawali Wally Porter, were filmed just months later by Ian Dunlop from the Commonwealth Film Unit, who had been tasked with making a documentary about the construction of Giles, Balloons and Spinifex (1958). Although a problematic film for other reasons, the good health of those filmed by Dunlop contrasts dramatically with the portrayal of their circumstances as shown by Grayden.

Yarnangu perspectives on this period of their history recorded during local viewings of Their Darkest Hour differ considerably to Grayden's portrayal of desert life as unviable. In its efforts to convince, the film failed to acknowledge the richness and strength of Ngaanyatjarra people's lives and the complexity of their engagement with the emerging modernity of the Western Desert under Australian colonialism. Many of the people in Their Darkest Hour are known and closely related to people who continue to live in the communities of the Ngaanyatjarra Lands. Some of those filmed by Grayden are still alive. When yarnangu today watch this film they do not see suffering strangers, but familiars - grandparents, mothers, children, lovers and enemies - who remain present in their immediate lives or their recent memories. There is a degree of pragmatism in many people's responses to Grayden's images of the physical hardships associated with living an independent bush life. People acknowledged that some individuals in the film were indeed very ill, expressing compassion for

71 Macaulay Patrol Report No 5, 8 March 1958, SROWA, Series 2030, Item 1956/0280.

72 These patrol reports are located in 'Military and Defence. Weapons Research Establishment, Reports and correspondence regarding Natives and Native Reserves', SROWA, Series 2030, Item 1956/0280.

73 The photographic collection of Robert Macaulay currently remains held privately by Macaulay. There are plans to permanently repatriate this collection to the Ngaanyatjarra Lands. His collection has, in the meantime, been digitised and re-documented with yarnangu to identify the names and biographical details of those he photographed. This research was undertaken by Pamela McGrath in 2008 and 2009 in conjunction with the re-documentation of Their Darkest Hour. 
their suffering with the phrase, 'Ngarltutjarra, poor thing!'74 But people also recognised that many were not, and rather this was how their lives had been at this point in their history. As one older woman put it after seeing her family in Their Darkest Hour, 'They had to be like that, living in the bush!'75

Grayden's camera could not convey to distant and unfamiliar audiences some of the crucial truths about desert life. Able to carry only a few material possessions, including clothes, it was a given that nomadic and semi-nomadic families lived with a high level of what most non-desert dwellers would consider discomfort and poverty. They were especially vulnerable to physical injury and hardly any adult was without the scars of serious burns, combat or disease. Not only did people have scars and other damage, but the lack of clothing meant they were visible for all to see. Their own society normalised their appearance to themselves, but at the best of times the body image of a desert Aborigine as conveyed through a camera was a challenge to the norms of well-being assumed by most audiences of 1950s urban Australia.

The differences between local and non-local responses to Their Darkest Hour epitomises what historian Tim Rowse has identified as an enduring confusion over the 'norms of wellbeing' associated with Indigenous health and living conditions in Australia. ${ }^{76}$ How do we determine the quality of life of an Aboriginal person whose social, cultural and economic circumstances differ so much from those of the 'average' westernised citizen? Being close to the edge foregoing clothes and most possessions - was crucial to Ngaanyatjarra people's ability to be highly mobile, which in turn was a pre-requisite to survival as a hunter-gatherer in an arid environment. It was a lifestyle that was both viable and desirable. The way the Aboriginal subjects of Their Darkest Hour looked largely went hand-in-hand with the fact that they were successfully choosing to continue to occupy their traditional lands in heart of the desert.

The film also portrays yarnangu as somehow separate from and ignorant of the outside world. But Ngaanyatjarra people of the 1950s might also be understood not as the passive victims of history - neglected, naïve inhabitants of a vanishing corner of the world - but as members of a society that had purposefully remained living in the desert at and around Warburton and north to the Rawlinson Range. Experience of a wider world that included the goldfields of Laverton and Kalgoorlie had existed among Ngaanyatjarra people since at least the 1890s, 60 years before Their Darkest Hour was made. Even the relatively isolated families of the Rawlinson Range had some knowledge of the 'outside' world, with members of their families having walked a route to Warburton and Laverton since at least the 1930s, a trip that took several weeks. Far from seeing themselves as flotsam tossed about by colonial forces unleashed in the wider world, yarnangu see their history and their circumstances during this period as largely the outcome of

74 Ngarltutjarra('poor thing!') is a Ngaanyatjarra term used to express one's sympathy or affection for someone or something, or one's sadness about a situation.

75 Watson, D, pers comm 18 May 2008.

76 Rowse 1998: 214. 
processes and events that they themselves have determined, or at least actively responded to. For example, the journey of the 'Famous Forty' filmed by Grayden at Mitika is remembered in family oral histories not as a great tragedy, but as an exceptional event, their arduous but courageous trek into the mission in November 1956 recalled with considerable awe. Similarly, the death of the man whose body was found at Mitika is attributed not to thirst but to a complex set of events resulting from his transgression of traditional Aboriginal Law in his Pitjantjatjara homelands many hundreds of kilometres to the east of Warburton. ${ }^{77}$ Many yarnangu interviewed about the film feel that Grayden's decision to film this man was insensitive, and people were shocked and horrified that a stranger had filmed his remains. More galling is the knowledge that images of his body are still in circulation and might be seen by members of his immediate family who are still alive and resident in the Anangu Aboriginal Lands of South Australia.

The question remains as to whether or not Grayden's narrow filmic portrayal of yarnangu lives was, in the end, worth the historical misrepresentation it has since perpetuated. It is emphatically the case that Grayden and Nicholls' cause was legitimate and humane insofar as they tried to bring the Western Australian government to account for its lamentable failure to engage with the circumstances of remote Indigenous people. Nonetheless the record shows that their efforts gained little ground for yarnangu in terms of material benefit despite the value to the Aboriginal rights movement nationally. Two years after the 'Warburton controversy', anthropologist Ronald Berndt concluded that while there had been some 'minor' changes to the social circumstances of Aboriginal people living in the Ngaanyatjarra region, few of these were attributable to the publicity generated by the Select Committee Report. ${ }^{78}$ Increased public awareness of the Aboriginal people living in the Western Desert resulted, however, in increased surveillance of their movements by the Western Australian government, and ultimately a loss of mobility (although not necessarily of social autonomy). ${ }^{79}$

The controversy created a political climate conducive to proposing significant legislative change designed to afford Aboriginal people of Western Australia citizenship rights, but in 1957 and 1958 two versions of the 'Natives (Status as Citizens) Bill' nevertheless failed to pass through the WA Legislative Assembly. ${ }^{80}$ What did endure, argues historian Sue Davenport, was a public image of Aboriginal suffering and starvation that was 'easily exploited' for political gain. ${ }^{81}$ The DNW was not insensitive to this. When Nicholls returned (albeit with

77 David Brooks first heard yarnangu talking about this matter when undertaking a field trip with Warburton people in the Mitika locality in 1989. At this time he had not heard of Grayden or of Their Darkest Hour. The cause of this man's death was raised in the WA Legislative Assembly in August 1957 following an unconfirmed press report that he had been murdered. Department of Native Welfare, SROWA, Series 2030, Item 1957/0384: 93.

78 Berndt 1959: 58.

79 Brooks 2002: 76.

80 The initial version of this bill failed to be passed after Grayden initiated a move to remove clauses which gave the Commissioner of Native Welfare legal guardianship over native children. See Berndt 1959.

81 Davenport et al 2005: 44. 
far less fanfare) to revisit circumstances in the Reserve in 1971, he was granted a permit only on the condition that he was not to take photographs of Aboriginal people without their prior consent. ${ }^{22}$ The most significant outcome of Grayden and Nicholls' advocacy in the Ngaanyatjarra area may well have been on the issue that is today referred to as 'stolen generations'. Grayden was a fierce opponent of the removal of children from the care of their parents, and in the Select Committee Report argued against plans to transfer all Aboriginal children from Warburton mission to the town of Cosmo Newbry. They were, in the end, never implemented. ${ }^{83}$

\section{Their Darkest Hour and the politics of representation}

The complex and at times positive responses of yarnangu to Grayden's images of friends and family in Their Darkest Hour mask deeper concerns felt by some yarnangu about the taking of Grayden's images. Research on the attitudes of Ngaanyatjarra people to the taking of films and photographs by outsiders has revealed a general distrust of strangers with cameras and considerable anxiety about the viewing of images that may cause others distress. In recent times, yarnang $u$ have taken various steps towards attempting to manage the 'hard look' of outsider image-makers but the digital age, which has been a boon in terms of the capacity to self-represent, has also made controversial images such as these very easy to reproduce and access. ${ }^{84}$ Such is the anxiety over the representations of outsiders that Ngaanyatjarra efforts have even at times influenced aspects of public self-presentation such as the structure of their communities. The Warburton Roadhouse, one of the main food, fuel and accommodation facilities for both yarnangu and travellers through the area, was built in 1985 at a location outside the community explicitly in order to keep the unwanted cameras and prying looks of casual tourists at a distance. That these concerns are in fact deeply felt is revealed if one looks at the minutes of the monthly Ngaanyatjarra Council meetings held over the past 30 years. They are rife with complaints from Ngaanyatjarra people about various violations of privacy. Such concerns are linked to a belief that photos showing squalor, evidence of petrol sniffing and the like are highly prized commodities in the media market. The images of Their Darkest Hour are seen in a similar light today. The debilitating sense of shame such images generate among yarnangu is pervasive and cannot be underestimated. Self-representation on its own only partially challenges the ongoing portrayal of people's lives by others.

In the context of the celebration of the 40th anniversary of the 1967 referendum, Their Darkest Hour and the events of the 'Warburton Controversy' have received renewed interest from filmmakers, museum curators, journalists, artists and

82 Department of Native Welfare, SROWA, Series 2030, Item 1972/001: 14.

83 Department of Native Affairs, SROWA, Series 2030, Item 1947/0076; Kral 2007.

84 Research carried out by Pamela McGrath towards her recently completed PhD thesis, 'Hard looking: an historical ethnography of the filming and photography of Ngaanyatjarra families'. A 'hard look' is a colloquialism sometimes used by yarnangu to describe the act of staring. 
academics. ${ }^{85}$ Working towards increasing the prominence of this important part of Australian history, filmmakers Rachel Perkins, Frances Peters-Little, Katherine Aigner and artist re a (Regina Saunders) have all utilised excerpts from Grayden's footage in film documentaries, at times using them to illustrate the impact of atomic testing on remote Aboriginal communities. ${ }^{86}$ Although permission for use was obtained from the Ngaanyatjarra Council prior to production in at least one of these instances, it appears that little was known about the actual history of the film. ${ }^{87}$ Nor, as far as can be established, were any Ngaanyatjarra people consulted about their opinions of film or the events it represents.

Towards the end of 2006 a group of Warburton Range artists who were participating in an exhibition celebrating 50 years of the Australian Broadcasting Corporation (ABC), Yours, Mine, Ours, were unexpectedly confronted with images from Their Darkest Hour in the work of $\mathrm{r}$ e a, an Aboriginal artist from Victoria. $\mathrm{r}$ e a had obtained the footage from the $A B C$ archive to use in a multimedia installation depicting seminal moments in the history of Aboriginal activism (which included Paul Keating's 1992 'Redfern Speech' and the 'Vote Yes for Aborigines' song) ${ }^{88}$ Among the Warburton artists were many young people who had never seen Grayden's film, or anything like it, previously. Their reaction was one of dumbfounded shock at seeing their families portrayed in this way. Agitated by this unexpected and unsanctioned use of images of their people, the Warburton artists requested that the multimedia work not be exhibited. After a failed attempt at mediation, the gallery eventually agreed. ${ }^{89}$ Guided by a senior spokesperson for their community, Livingston West, and the Coordinator of the Warburton Arts Project, Albie Viegas, the Warburton artists collaborated to quickly produce a body of work that expressed their responses to the film. A series of powerful paintings about the filming of Aboriginal people by outsiders, and about Their Darkest Hour specifically, were subsequently included in the Yours, Mine, Ours exhibition..$^{90}$ These works offered a frank assessment of the

85 See for example Attwood and Markus 2007; the National Museum of Australia's on-line history of Aboriginal activism, Collaborating for Indigenous Rights (2008), edited by Sue Taffe, <http:// indigenousrights.net.au/section.asp?sID=1>; 'Yes vote inspired by horror', The Australian, 12 October 2007: 4.

86 In her television documentary The First Australians, Rachel Perkins used footage of Doug Nicholls tending a group of naked children at Giles immediately before an image of the 'mushroom cloud' of a Maralinga test. The intention is clearly to draw an association between the two. Frances PetersLittle does much the same in her documentary Vote Yes for Aborigines (2008). Katherine Aigner's film Australian Atomic Confessions (2004) uses numerous scenes from Their Darkest Hour, including Nicholls examining a child at Mitika, the baby with a burn on its leg, and the burial of the human remains. She describes the children and the baby as having 'beta radiation burns' from the atomic tests. The artist $\mathrm{r}$ e a described Grayden's film as providing evidence of 'the absolutely devastating physical impact that the British nuclear tests had on the Pitinjarra [sic] people the traditional owners of the "bombed" land". See r e a's exegesis of maang (part 2, 2006) at: <http:/ / www.aucklandtriennial.com/2007/artists/rea. asp?pageType= print (accessed 6 June 2010).

87 Peters-Little, F, pers comm 25 February 2009.

88 This artwork has not been viewed by either author. Details of the installation were provided by Warburton Arts Coordinator at the time, Albie Viegas.

89 Havilah, L, curator of Campbelltown Gallery, Sydney, pers comm 9 January 2007.

90 An example of these artworks can be found at: <http://www.abc.net.au/tv/yours/artists/ landers.htm> 
emotional and political impact of Grayden's film for these artists in work that depicted the unwelcome gaze of strangers in general as 'hard', dangerous and without compassion. Their titles alone are telling: Nyakulayinu Tarrkanu (literally 'looking until all that is left is bones'); Nyakula Papulankupayi (literally 'staring at us without recognition'); and Looking is Deadly.

Accompanying these works of art was an open letter from Livingston West to the ABC. West's letter directly addresses the perceived role of Their Darkest Hour in perpetuating misguided stereotypes of yarnangu as helpless suffering victims, and of desert communities being marginal and unviable. His suggestion that access to such films of Ngaanyatjarra people be restricted speaks to concerns about the capacity of the media and the general public to see beyond the images of Their Darkest Hour to a more complex and ultimately positive understanding about the character of remote Aboriginal lives:

Kurnta [shame], it's shaming to be seen like that. Don't show that film [in the Sydney exhibition]. It'll be like discrimination ... Put that film away. Put it away, for history. Hold it, but don't show it to people.

They still look at Aboriginal people. They don't recognise and still think that Aboriginal people in that time, eating that meat and the flies, they think still they doing that today.

Yes, they used it for the referendum, I understand that [but] they made it bad, because they didn't understand what they were doing.

It's still the same now ... Instead of encouraging them to stand on their feet, they put them down. Show the worst things. ${ }^{91}$

The $A B C$ responded to West's letter by identifying the archival footage of Grayden's film as 'culturally sensitive' and restricting access. ${ }^{92}$ Anyone wishing to access the footage must now secure approval from the Ngaanyatjarra Council. This was, in the circumstances, the most appropriate course of action for the $\mathrm{ABC}$ to take. But the fact that this film has been circulating in the public domain for over 50 years and represents a significant moment in the political history of many other Aboriginal people, makes this a particularly contentious move. What rights do others (Indigenous and non-Indigenous alike) have to access the images of Their Darkest Hour so they too can witness and make up their own mind? How should such rights be positioned in relation to calls from yarnangu to respect their privacy and allow them some control over photographs and films of family members, depicted in circumstances that are distressing or shaming? These questions are not easily answered. What is clear, however, is that the significance of Grayden's and Nicholls' advocacy cannot be fully understood until historical accounts about these events move away from relying on the images of Their Darkest Hour, and give greater consideration to the perspectives of the Aboriginal people whose lives the film purports to represent. While

91 West 2006.

92 Havilah, L, curator of Campbelltown Gallery, Sydney, pers comm 9 January 2007. 
these perspectives may at times challenge the narratives of other historians and filmmakers who are themselves attempting to re-write history from the margins, they remain crucial to understanding the full complexity of the cultural and historical moment that was the 'Warburton controversy'.

\section{References}

\section{Archival sources}

\section{Australian Institute for Aboriginal and Torres Strait Islander Studies}

Horner, Jack, 'Provenance of “Warburton Range" Film of 1957, 11 November 1982', GRAYDEN_FILM/VIDEO_01 LV0356.

Francis, Sarah 1980, 'Noonkanbah blacks reject WA minister's threats [response to W Grayden's taped message to Noonkanbah people regarding drilling on Aboriginal sites]', SF 32/1.

\section{National Archives of Australia}

Australian Security Information Organisation (ASIO) Central Office, Series A6122/44, Subject files, Item 1524, 'Communist Party of Australia - Interest in personalities and associations - Aborigines Volume 1', vol 1, 1956-1958, barcode 1179735 .

Commonwealth Bureau of Meteorology Regional Office Western Australia, Series PP470/1, Correspondence files, Item 761, 'Giles Weather Station', 19561972, barcode 1570758 .

Department of Territories Central Office, Series A452/54, Item 1957/245, 'Welfare of Aborigines - Warburton Ranges area', 1956-1961, barcode 1878758.

State Records Office of Western Australia

Series 268 Files - General - Central Board of Health, 1899-1987, Item 1957/0283, 'Native Affairs - Warburton Ranges - Survey of living conditions of Natives by Dr Davidson and Staff', Consignment no 1003.

Series 2030 Files - Aborigines Departments - Department of Native Affairs, 19261972, Item 1947/0076, 'Military and defence guided projectors', Consignment no 993. 
Series 2030 Files - Aborigines Departments - Department of Native Welfare, 1926-1972, Item 1956/0280, 'Military and Defence. Weapons Research Establishment, Reports and correspondence regarding Natives and Native Reserves', Consignment no 993.

Series 2030 Files - Aborigines Departments - Department of Native Welfare, 19261972, Item 1957/0040, 'Warburton Ranges and surrounding districts. Living conditions of natives in area, Investigations and reports of', Consignment no 993.

Series 2030 Files - Aborigines Departments - Department of Native Welfare, 19261972, Item 1957/0384, 'Warburton Ranges and surrounding districts. Living conditions of natives in area, Investigations and reports of', Consignment no 993.

Series 2030 Files - Aborigines Departments - Department of Native Welfare, 1926-1972, Item 1972/001, ‘Visit to Warburton Ranges, Wingellina Areas April 1971 by Pastor Doug Nicholls and Dr Kevin Henrichsen', 1970-1972, Consignment no 1724.

\section{Other archival sources}

Elphinstone, JJ 1958, 'Report on Health and Nutrition of Native from Rawlinson Range to Lake MacDonald', unpublished report for Department of Public Health Western Australia, Mark Chambers Collection, Perth.

Ferrell, John 1989, 'Verbatim transcript of an interview with Hon. William Leonard Grayden: Early life experiences and parliamentary career', JS Battye (ed), Library of West Australian History and the Australian Parliament, Perth.

Hughes, Robin 2009, 'Interview with Faith Bandler, 25 March 1993', Australian Biography Online, accessed 6 January: <2009http:/ / www.australianbiography. gov.au/subjects/bandler/interview6.html>

Jamieson, Rhonda 1986, 'Verbatim transcript of an interview with William Leonard Grayden', in The Western Australian Parliamentary History Project, Parliament of Western Australia and Library Board of Western Australia, Perth.

West, Livingstong 2006, Response to ABC archival footage taken in 1957 in Warburton Mission, filmed by Bill Grayden and featured in the Paul Robeson in Australia documentary (1964). Penrith Regional Gallery and the Lewers Bequest, Penrith. 
Newspapers

The Advertiser

The Australian

Daily News

The Herald

The News

People

The Sun

Sydney Morning Herald

The West

West Australian

\section{Secondary sources}

Attwood, Bain 2003, Rights for Aborigines, Allen \& Unwin, Crows Nest.

- 2005, Telling the Truth About Aboriginal History, Allen \& Unwin, Crows Nest.

Attwood, Bain and Andrew Markus 2007, The 1967 Referendum: Race, Power and the Australian Constitution, Aboriginal Studies Press, Canberra.

Berndt, Ronald 1957, 'The "Warburton Range" controversy', The Australian Quarterly XXIX(2): 29-44.

- 1959, 'Native welfare in Western Australia since the "Warburton controversy" of 1957', The Australian Quarterly 31(3): 57-72.

Brooks, David 2002, 'What impact the mission?', in Mission Time in Warburton, V Plant and A Viegas (eds), Warburton Arts Project, Perth.

Clark, Jennifer 2008, Aborigines and Activism: Race, Aborigines and the Coming of the Sixties to Australia, University of Western Australia Press, Crawley, Western Australia.

Clark, Mavis Thorpe 1965, Pastor Doug: the Story of an Aboriginal Leader, Lansdowne Press, Melbourne.

Curthoys, Ann 2002, Freedom Ride: a Rider Remembers, Allen \& Unwin, Crows Nest. 
Davenport, Sue, Peter Johnson and Yuwali 2005, Cleared Out: First Contact in the Western Desert, Aboriginal Studies Press, Canberra.

Gara, Tom 2003, 'Explorers and prospectors', in Trust, Jan Turner (ed), Warburton Community Incorporated, Alice Springs.

Grayden, William 1957, Adam and Atoms, Frank Daniels Pty Ltd, Perth.

- 2002, A Nomad Was Our Guide: The Story of a Journey through the Land of the Wongi - the Central Desert of Australia - 1953, NH Holdings Publications, South Perth.

Hawke, Steve, and Michael Gallagher 1989, Noonkanbah: Whose Land, Whose Law, Fremantle Arts Press, Fremantle.

Horner, Jack 2004, Seeking Racial Justice. Aboriginal Studies Press, Canberra.

Kerin, Rani 2004, “"Doctor Do-good”?: Charles Duguid and Aboriginal politics, 1930-1970s', PhD thesis, Department of History, Australian National University, Canberra.

Kinnane, Steve 2007, 'The Coolbaroo League', in Historical Encyclopaedia of Western Australia, Department of History, University of Western Australia, Perth, accessed 6 January 2009: <http:/ / www.encyclopedia.uwapress.uwa. edu.au/wa_snapshots\#c>

Kral, Inge 2007, 'Writing words - right way!: literacy and social practice in the Ngaanyatjarra world', PhD thesis, Department of Anthropology and Archaeology, Australian National University, Canberra.

Langton, Marcia 1993, 'Well I Heard it on the Radio and I saw it on the Television...', Australian Film Commission, Woolloomooloo.

McGrath, Pamela F 2004, 'Guilty as charged: Assimilation, Atom Bombs, Aboriginal Activists and W.L. Grayden's 1957 film Manslaughter', Masters of Arts Preliminary Thesis, School of Social Sciences, La Trobe University, Melbourne.

Morton, Peter 1989, Fire Across the Desert: Woomera and the Anglo-Australian Joint Project 1946-1980, Australian Government Publishing Service, Canberra.

Peters-Little, Frances 2002, 'The return of the noble savage by popular demand: a study of Aboriginal television documentary in Australia', MA Thesis, Australian National University, Canberra.

Rowse, Tim 1998, White Flour, White Power: From Rations to Citizenship in Central Australia, Cambridge University Press, Melbourne. 
Simmons, Rennie 1957, Analysis of Mr. Rupert Murdoch's Article on the West Australian Natives published in 'The News', Adelaide, February 1st, 1957, Challenge Press, Coburg, Victoria.

Taffe, Sue 2005, Black and White Together: FCAATSI, The Federal Council for the Advancement of Aborigines and Torres Strait Islanders 1958-1973, University of Queensland Press, St Lucia, Queensland.

- (ed) 2008, 'Nomads and nuclear testing', in Collaborating for Indigenous Rights, National Museum of Australia, accessed 10 December 2008: <http:/ / indigenousrights.net.au/>

Victorian Aboriginal Advancement League 1985, Victims or Victors? The Story of the Victorian Aborigines Advancement League, Hyland House, South Yarra. 